\title{
TOURISM AND EMPIRE: AN INVITATION TO COLONIAL TRAVEL
}

Maria João Castro

Universidade Nova de Lisboa

Data recepción: 2016/10/10

Data aceptación: 2018/04/11

Contacto autora: mariakastro@gmail.com

ORCID: https://orcid.org/0000-0003-1443-7273

\section{RESUMO}

Um dos temas mais prementes da história da arte contemporânea tem a ver com o binómio império/turismo, encontrando-se ambos profundamente interligados, uma vez que a colonização impulsionou a criação de novas mobilidades. Inicialmente, as viagens das Descobertas limitaram-se à conquista, missionação e comércio, mas a partir do século XIX - a viagem colonial tornou-se num imperativo político, social, cultural e artístico. Na verdade, a partir do final de Oitocentos, a política imperial europeia promoveria a viagem às possessões ultramarinas não só para (re)definição geográfica do território mas principalmente como reflexo dos nacionalismos europeus emergentes, tornando-se num meio privilegiado de legitimação e de propaganda das províncias d'além mar. Esta dinâmica fez com que o turismo colonial se desenvolvesse a vários níveis e em diversas frentes, promovendo uma vilegiatura ultramarina que se tornou num dado civilizacional medidor da cultura contemporânea.

Palabras chave: turismo, império, arte d'Além Mar, viagem, herdança colonial

\section{ABSTRACT}

One of the most compelling topics in the history of contemporary art is the empire/tourism binomial. The two are closely interconnected, as colonisation was a driving force behind the creation of a new kind of mobility. In an initial phase, voyages of discovery were concerned solely with conquest, missionisation and trade, but from the 19th century onwards travel to the colonies became a political, social, cultural and artistic imperative. In fact, after the end of the 19th century, European imperial policy encouraged travel to overseas possessions not only as a means of (re)defining territory in a geographical sense but primarily as a reflection of emerging European nationalism, turning travel into a privileged means for legitimating the overseas provinces and for spreading propaganda about them. As a result, colonial tourism developed on various levels and fronts, promoting an overseas holiday experience that became a civilisational datum and a gauge of contemporary culture.

Keywords: tourism, empire, art from overseas, travel, colonial heritage

\section{Introduction}

From the Roman leisure tour along the Mediterranean coast through the medieval pilgrimage to the Grand Tour, there exists a whole travel genealogy which impacted on the colonial trajectory in the 19th century and induced a number of people from the metropole to head towards the
African and Asian colonies of the empires of the Old Continent.

This trajectory of colonial travelling in the 19th and 20th centuries was the result of a series of well-known conditions: the development of means of transport resulting from the Industrial Revolution, an increase in leisure time and a bour- 
geoisie with money who began to want to copy the nobility in their taste for travel. In addition to this, new ideas about well-being (and health) and leisure encouraged the proliferation of tourism, with the colonies becoming a favourite destination for this European quest. In fact, empire and industrialisation became allies in the sense that they created a new cultural reality: the development of shipping and railway companies, the support given to journeys of exploration in the African continent with the purpose of drawing boundaries and the increased colonial support infrastructure (hotels, access roads, architecture) all spurred people on to travel to the European colonial possessions especially and to remote parts of the globe by creating the conditions necessary for a successful journey.

\section{Corpus}

\section{Universal and World Exhibitions}

After the second half of the 19th century (to be precise, after 1851 - the year of the first universal exposition in London), the growing importance of these world-universal (later colonial) events introduced the new overseas geographies into the capitals of the empires (initially London and Paris where the first exhibitions were held). This fostered a mythical desire in the societies of the metropole to experience these places following the call of the exotic, the echo of which has survived until today. Without a doubt, the "discourses" shown in these exhibitions - where recreating indigenous scenarios was first done so that later the natives themselves could be introduced in villages built for the purpose - were a form of colonial cum tourist propaganda with a strong imperial stamp seeking to legitimate the ownership of such overseas possessions as well as to show the civilizational power of the Old Europe. The popularity these events acquired created a desire to leave, a desire to follow in the footsteps of the 19th century explorers and missionaries. At the very first exhibition in 1851 in London, British India occupied pride of place in the event, demonstrating the importance of the British 'jewel in the crown'. At the 1889 Paris Exhibition, and in the shadow of the Eiffel Tower, the centenary of the French Revolution, and con- sequently of the French Empire, was commemorated. This was the first exhibition to include a true colonial section for the history of France and the one that would mark the beginning of a model for colonial representations that would last during the final quarter of the 19th century and for the whole of the 20th century. In fact, the area in Paris reserved for showing the colonies was located in the Champs de Mars and was a tableau vivant divided into four zones - Arabia, Oceania, Africa and Asia. In the 1900 Exhibition, this would grow into a much vaunted "tour du monde" but without the visitor ever leaving Paris'. Integrated within the imperial landscape of the French colonies (especially the Asian ones) was the human landscape that brought the picture depicted to life reproducing ethnographically the boundaries of the empire. These recreations were of course fed by a prolific supply of literature, the majority of which written by Frenchmen on diplomatic missions to the colonies (as was the case of Pierre Loti), through which the imagination of the urban public could "prolong" their colonial fantasies after the exhibitions had closed their doors.

The exhibitions themselves were the pretext for writing travel notes about this colonial worldview that was recreated in the empires' capitals, and among these can be included various Portuguese accounts that are as yet little known². But the relationship between this travel literature and the imperial conquest/representation also enabled a "discourse of desire" to be constructed which strengthened and helped to legitimate the act of conquest and imperial dominance (Holland $2003,15)$. The success of the colonial sections in the world and universal exhibitions led to the appearance of their own type of event - colonial exhibitions - which were events that enjoyed huge popularity. Authentic "living showcases" of European imperial possessions, not only were representatives of indigenous peoples integrated within them but also native environments were recreated in real "human zoos" (Thuram 2011). This led many of the visitors to accept the invitation to undertake a colonial journey to discover the empire. 


\section{Arts and the colonial context}

The promotion of the colonial journey was not, however, limited to the world, universal and colonial exhibitions. Even though these played an effective role in attracting people to visit the overseas territories, there were other practices that reiterated this same purpose. In the arts, numerous artists were driven to discover these faraway scenarios and different pictorial motifs. This gave rise to a distinctive plastic and aesthetic discourse which influenced the arts both at home and overseas. Take, for instance, the case of Eugène Delacroix (1798-1863) in North Africa, Paul Gauguin (1948-1903) in French Polynesia or Henri Matisse (1869-9154) in French Polynesia and Morocco, all of whom have been studied in depth. Naturally, the colonial journey had bilateral consequences since it not only enabled the sphere of imperial influence to be increased in the overseas territories but also influenced the culture and the arts of the European metropoles. In fact, as Edward Said argues in his work Culture and Imperialism, "European cultural production reflected the efforts made to construct and maintain the overseas empires" (Said 2011: 143). Colonial travelling therefore played an important role in the legitimation and maintenance of the overseas possessions so that a great deal of attention was paid to overseas policy in order to create a dynamic that would facilitate the journey from the mother-nation to the colonised territories.

In this context, the belief that the empire was beneficial to both territories - the metropole helped the colony to "become civilised" while in exchange the latter enabled the empire to become stronger in the political-cultural field - governed the concerns of western governments, principally between the years 1850 and 1950. Said in another way, from the second half of the 19th century on, European empires encouraged metropolitan citizens to travel to their colonies after having realised that this functioned as a type of vector through which imperial nationalism could be spread and consolidated, thereby legitimating it. To this end, a whole structure for colonial propaganda was set up, the objective of which was to spread information about these overseas destinations. What is noticeable here is that a wide range of literature (brochures, magazines, guidebooks) was developed along with literary competitions although the main impulse came from the trend for official trips by Heads of State, which will be dealt with in more detail below.

Furthermore, what can be seen is the appearance of a mentality that went against modern society, one which was looking for an experiential authenticity based on ancestral cultures in a return to the "primitive" state which might restore a certain notion of belonging; one which sought to plunge into our primordial roots and which passed through capitalism and neo-liberalism, and still remains in an age of globalisation, becoming one of the fundamental issues of our time. In this respect, we are witnessing the mythification of European colonial empires when, for example, in the $19^{\text {th }}$ century Indochina is termed the "pearl" of the French Empire, India is the "jewel" in the British crown and even the State of Portuguese India becomes the "pearl" of the Portuguese Empire. If it is true that these territories were not unknown, it is also true that they were not particularly well known but were fictionalised in shows (exhibitions, literature) that helped to create an aura of exploration and seduction that drove people to "exploit" them.

As Eric Hobsbawm so clearly put it, the 19th century was the "Age of Empire" (Hobsbawm 1990) and this had wide repercussions on the mode in which people, both the colonisers and the colonised, travelled. What is more, there are even those who advocate that it was due to empire that tourism came to the fore and developed on a global scale; for example, see what the historian Jim Davidson says in Holiday Business: Tourism in Australia since 1870 when he suggests that Thomas Cook ${ }^{3}$ was really the person responsible for the emergence of tourism in Australia and New Zealand by capitalising on the journey to the British colonies in the Antipodes (Davidson 2000).

It is clear that the role of the arts, which helped people to "see" the lands of the distant empire for the first time, greatly contributed to such tourism becoming consolidated. This was common to all the European colonial empires and had consequences within the arts of the Old Continent since it allowed new thematic content (landscapes, portraits, local customs and the picturesque) 
to be introduced as well as novel forms of reproducing a new reality, particularly in regard to new pigments and new ways of capturing the African light, so different to the European light. Above all, this new pictorial world provided by colonial travelling gave new impetus to and revitalised western art itself.

\section{The Estado Novo and Tourism}

From the Portuguese point of view, the relationship between tourism and State was consolidated during the dictatorship of the Estado Novo (1926-1974) despite the fact that the genealogy of Portuguese tourism had started during the First Republic (1910-1926). However, as a political proposition, the dynamic of national tourism really took off in the 1930s and enjoyed the unique characteristic of continuing after the fall of the Old Continent's colonial empires following the end of the Second World War. In reality, the gradual independence of European overseas territories after 1945 contributed to the massification of tourism on a world scale which has led some scholars to classify it as a new form of imperialism, a fact that we shall deal with at the end of this article.

It is important to mention that there was a practical concern by the Estado Novo at the national level to take upon itself the job of structuring a policy of colonial tourism propaganda. Of course to develop this scenario it was first necessary to set in motion a series of actions to help structure such a design, beginning with the drawing up of a policy for domestic tourism. In this context, the Secretariado de Propaganda Nacional [SPN - National Propaganda Secretariat], the body responsible for the Repartição do Turismo [Office of Tourism] ever since it was created in 19334, immediately considered that "tourism, besides being an indisputable factor of enrichment and civilisation, was a very safe way to carry out intense national propaganda as well as simple political propaganda" (Direcção Geral de Turismo 1991: 9). This meant that tourism could be used as a tool to strengthen national identity and reinforce the role of the state as guardian of cultural (particularly monumental) heritage, which attests to the grandeur of the nation. It was not directly an incentive to the massification of tourism or even promotion of tourism to the colonies but it was the start of a new way of thinking.

With such a proposition in mind, the 1933 Portuguese Constitution itself alluded to the bond existing between the regime and tourism when, in Article 52, the text referred to the primacy attributed to national heritage when it declared that "artistic, historical and natural monuments are under the protection of the State as are artistic objects officially recognised as such". Supported by this legal framework, they then set out to define a policy for tourism which advanced on various fronts: a campaign to reportuguesify the country in which a range of initiatives of a ruralist nature were undertaken that proposed to revive and keep alive national traditions, and among which the following stand out - the competition for the most Portuguese village in Portugal, the creation of folklore groups and the setting up of the Museu de Arte Popular [Museum of Popular Art], the rebuilding of the country's architectural heritage and the development of Regional Pousadas [or hotels] as part of the "Plano de Realizações do Duplo Centenário de 1940" [Plan of Actions for the Double Centenary of 1940] endorsed by Duarte Pacheco's Ministry for Public Works and considered true postcards of the different regions of the country; the setting up of a review, Panorama - Revista Portuguesa de Arte e Turismo, an informative publication about national tourism edited in four series between 1941 and 1973, which publicised the official tourist image by giving enhanced value to the folklore side of tourism together with references to the arts supported by the regime; the publication of brochures, posters, maps and books which updated the image of Salazar's new Portugal and of which the books Images Portugaises (SPN, 1939) and Paisagem e Monumentos de Portugal (Santos 1940) are two examples; the start of the Fundação Nacional para a Alegria no Trabalho [FNAT - National Foundation for Happiness at Work $]^{5}$ which drew up a social tourism policy that included the organisation of holiday camps and promoted outings and excursions to places of historical interest; the creation of a weekly programme on the national radio station Emissora Nacional, written by the Tourism Service called "Conheça a sua Terra" [Know your Country] which publicised Portugal's natural beauty 
spots, monuments, ethnography and folklore, and also promoted excursions in the Lisbon region and surroundings. This campaign was later extended to the colonial provinces as they were considered a part of Portugal as we will see later.

According to António Ferro (1895-1956), the Secretary of the SPN which coordinated the Estado Novo's cultural and artistic policy, enhancing the value of mainland Portugal had to be done through focusing on popular resources, thereby constituting an alternative to the doubtless more erudite and cosmopolitan European tourist destinations in comparison with which he believed the national reality had little to offer. In fact, the legislative movement relating to tourism fell within a wider policy concerning the development of public works and which encompassed improvements to road and transport networks, basic sanitation and communications, the restructuring of existing hotels and the planning of new ones according to pre-established precepts. At the same time it included tourist propaganda campaigns that not only provided the structure for tourism in the metropole but also boosted the development of colonial travelling (and in the future, tourism) creating the key conditions required for overseas journeys to be undertaken. Even though indirectly, the premises referred to above motivated an elite to get to know the far corners of the empire, often allying a professional placement (military or business) to leisure as well as promoting colonial travel and stimulating the creation of support infrastructures that could cater for a broader group such as relatives and friends.

This multifaceted tourist propaganda action dealt with by the SPN was carried out within the so-called Politica do Espírito [Policy of the Spirit]. This sought to showcase a rural country populated by worthy people who had carried out memorable feats in the past but which was also the mother-country of a great empire, the possessor of a culture that was independent, all its own and ready to be shown to the world in its various dynamic aspects, especially in its overseas territories.

\section{Travel as a vehicle for colonial propaganda}

Initially, nevertheless, tourism to the colonies intercontinental tourism - was little encouraged. Although it had been the monarchy's intention to do $\mathrm{so}^{6}$, it was the Estado Novo in 1934 who would actually instigate colonial tourism with the enactment of Decree-Law $n^{\circ} 23445$ of 5th January 1934. This established the first fledgling government agencies in the provinces - the Casas da Metrópole [Metropole Offices] - whose function was to promote tourism, a process which would continue until the creation in 1959 of the Centros de Informação e Turismo [Tourism Information Centres]' in the overseas provinces, and which had their beginnings in the Feiras de Amostras Coloniais [Colonial Produce Fairs] of the 1930s in the African provinces ${ }^{8}$.

The Casas da Metrópole were the brainchild of José Pedro Alvares, President of the Associação Industrial Portuguesa [Portuguese Industrial Association]. Their purpose was to set up in the colonies a "permanent showcase for goods and products originating on the European continent for consumption overseas", but which in order to be "more than just a small museum, should be adjoined to an information and propaganda section". In addition, it was through these that the Concursos de Arquitectura, Escultura, Pintura e Desenho [Architecture, Sculpture, Painting and Drawing Competitions] were promoted and the first Painting Salons established".

The idea behind these Casas da Metrópole was complemented by the creation of Casas das Colónias [Colonial Offices] in the Portuguese capital. Armindo Monteiro was given the ambitious task of setting up a "permanent industrial and commercial showcase in the Agência Geral das Colonias [AGC - General Agency for the Colonies] (Portugal Colonial 1932: 16-17: 40). Later on it became part of the plans for a Casa Colonial [Colonial House], completing the triangle of the Museu Colonial [Colonial Museum] in Belém, which was never built, the Museu Etnográfico in the Sociedade de Geografia (the Geographical Society's Museum of Ethnography) and the permanent Showcase Exhibition in the Agência Geral das Colonias. As regards the Centros de Informação e Turismo, these were coordinated by the Agência Geral do Ultramar (General 
Overseas Agency), which provided the necessary guidance, although dependent on local government $^{10}$. Simultaneously, the decree-law which created the Centros de Informação e Turismo in Angola, Mozambique and India ( $n^{\circ} 42194$ of 27th March 1959) ordered the closure of the Casas da Metrópole in Luanda and Lourenço Marques $^{11}$ and legislated the transfer of their holdings, assets and employees. The same law entrusted the Overseas Minister with the establishment of identical government agencies in the provinces of Cape Verde, Guinea, São Tomé e Príncipe, Timor and Macau in 1960 ${ }^{12}$. In sum the Casas da Metrópole and the Centros de Informação e Turismo constituted a process at first commercial and propagandistic but ultimately related to tourism, which reflected the growing importance of the latter in the colonial context. Though concerns about overseas political and tourism development would come later, already in 1935, commensurate with institutional wishes, the $1^{\circ}$ Cruzeiro de Férias às Colónias [ $1^{\text {st }}$ Holiday Cruise to the Colonies] was organised through the initiative of the magazine Mundo Português. The Salazar government, realising the nationalist import of such a venture, offered its full support and protection as Portuguese patriots rushed to sign up as passengers. Via detailed reports the whole country was invited to accompany these "ambassadors from the motherland to the distant sons of the nation" (Roteiro do $1^{\circ}$ Cruzeiro de Férias às Colónias 1935: 6) In reality the cruise allowed a group of students and teachers to directly experience the Portuguese African colonies owing to the pedagogical criteria governing the trip, although the overall objective was to instil a sense of Portugal's grandeur in the world. The voyage included the colonies of Cape Verde, Guinea, São Tomé e Príncipe, and Angola and enjoyed the collaboration of the local authorities ${ }^{13}$. In the context of modern travelling practice the $1^{\circ}$ Cruzeiro de Férias às Colonias was a decidedly colonial act, comprising a sovereign journey of national and international exposure with political intentions of cultural subordination and economic attainment. But equally it was a weapon which predisposed people towards the acceptance and defence of colonial policy while at the same time acting as a driving force in the mobilisation of Portuguese emigration and settlement in the African territories.

Two years after the $1^{\circ}$ Cruzeiro de Férias às Colónias, there followed the $1^{\circ}$ Cruzeiro de Férias de Estudantes das Colónias à Metrópole [1st Holiday Cruise for Students from the Colonies to the Metropole] in 1937 - the outcome of another initiative by the magazine Mundo Português. On this occasion some of the students, the sons and daughters of colonos, or settlers, in Angola and Mozambique, were given the opportunity to visit the Exposição Histórica de Ocupação [Historical Exhibition of Occupation] and afterwards take part in an excursion from the north to the south of Portugal ${ }^{14}$. The aim of both cruises was to firmly establish the collective conscience with regard to the colonies in the first case and to the motherland in the second - an aim which was amply fulfilled.

Nonetheless it was clear that the example should come from above. While the President of the Council, Oliveira Salazar, was not interested in getting to know the overseas reality, in 1938 the Head of State Óscar Carmona (1869-1951) embarked on his first overseas trip visiting the colonies of São Tomé e Príncipe and Angola. The following year he travelled to Cape Verde and Mozambique. In a crystallised metropole which was at the time impervious to any wind of change and as a way to mark the second journey for posterity, it was decided to carve an inscription in stone on the pillars of the Cais de Colunas [the two pillars on the waterfront at Terreiro do Paço]. Inscribed on the left-hand pillar, near where Portuguese ships had previously set sail on the voyages of Discovery, were the following epic words:

SEGUNDA VIAGEM DO CHEFE DO ESTADO ÀS TERRAS ULTRAMARINAS DO IMPÉRIO: CABO VERDE, MOÇAMBIQUE E ANGOLA. XVII DE JUNHO - XII DE SETEMBRO DE MCMXXXIX A VIAGEM DO CHEFE DO ESTADO ÀS TERRAS DO IMPÉRIO EM ÁFRICA ESTÁ NA MESMA DIRECTRIZ DAS NOSSAS PREOCUPAÇÕES E FINALIDADE, É MANIFESTAÇÃO DO MESMO ESPÍRITO QUE PÔS DE PÉ O ACTO COLONIAL. SALAZAR

[The second voyage of the Portuguese Head of State to the overseas territories of the empire: Cape Verde, Mozambique and Angola. 17th June12th September MCMXXXIX. The voyage of the 
Head of State to the imperial territories in Africa is commensurate to our concerns and ends. It demonstrates the same spirit of colonial endeavour. Salazar]

On the right-hand pillar the President of the Republic said:

AQUI EMBARCOU O CHEFE DO ESTADO PARA A PRIMEIRA VIAGEM A TERRAS ULTRAMARINAS DO IMPÉRIO S. TOMÉ E PRÍNCIPE E ANGOLA. XI DE JULHO - XXX DE AGOSTO DE MCMXXXVIII COM A CERTEZA DE QUE FALA PELA MINHA VOZ PORTUGAL INTEIRO, PROCLAMO A UNIDADE INDESTRUTIVEEL E ETERNA DE PORTUGAL D' AQUÉM E ALÉM MAR! GENERAL CARMONA

[From here embarked the Head of State on the first voyage to the overseas territories of the empire, $S$. Tomé e Principe and Angola. 11th July-30th August MCMXXXVIII. With the certainty that my voice speaks for all Portugal, I proclaim the indestructible and eternal unity of Portugal at home and overseas! General Carmona]

However, the return of the President to the Cais das Colunas on 12th September 1939 symbolised a new era in that Carmona was returning to a continent under the shadow of war (fig. 1). The Second World War had been declared on 1st September forcing Oliveira Salazar's government to declare Portuguese neutrality ${ }^{15}$.

These journeys were important in that some metropolitan citizens decided to follow in his footsteps, thereby increasing travel to the colonies.

In 1954 Craveiro Lopes (1894-1964) was despatched to the provinces of São Tomé e Príncipe and Angola; in 1955 he travelled throughout Guinea and Cape Verde, and in 1956 to Mozambique. In the 1960s it was the turn of Américo Thomaz (1894-1987) who visited Angola and São Tomé e Príncipe in 1963, Mozambique in 1964, Guinea and Cape Verde in 1968, and finally São Tomé again in 1970. Marcelo Caetano (1906-1980) travelled to Guinea, Angola and Mozambique in 1969. Voyages to the ex-colony of Brazil were undertaken by António José de Almeida (1866-1929) in 1922, Craveiro Lopes in 1957, Marcelo Caetano in 1969 and Américo Thomaz in $1972^{16}$. What was important was not only the fact that these official visits constituted

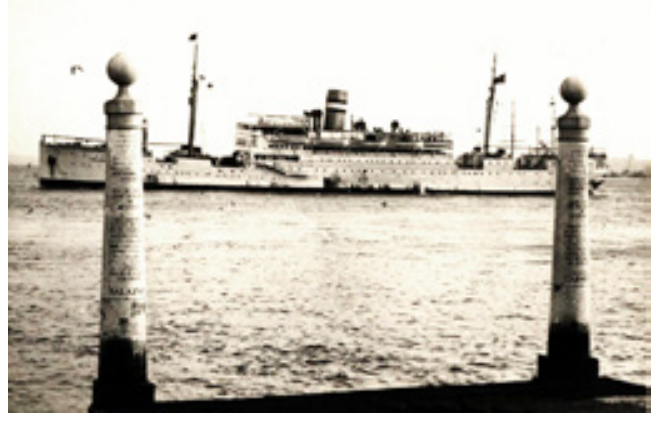

Fig. 1. President arriving at Cais das Colunas, Lisboa, 1939

the high points of a political propaganda focused on the reaffirmation of Portuguese sovereignty over its African colonies in the face of both national and international public opinion, but also the fact that they opened the way for the restructuring and development of an imperial policy which began to consider the tourism potential of these overseas territories. This was especially so because they showed visually (through the press and television) a place that had earlier belonged to the Portuguese Empire which, besides enjoying a shared history, even had the same language. Both of these facts contributed in the long run to many Portuguese people deciding to travel to become acquainted with this destination whose past was so closely linked to Portugal.

In the Anuário do Turismo do Ultramar de 1959 [1959 Directory of Overseas Tourism] it is stated that "from the Atlantic to the Indian Ocean, from Oceania to the Far East of Asia, to the very limits of Portuguese territory, the conditions for tourism are truly exceptional. Now that people everywhere travel and the world has become smaller (...) the colonies must equip themselves for the creation of a new industry: tourism." (Anuário do Turismo do Ultramar de 1959 1960:1-2) After praising the tourism potential of each overseas province the report observes that "something has been achieved in Mozambique and Macau" but urges that much more needs to be done, not only to "attract foreigners but to remind us of the ever present lessons of a Past which many are not aware of and others have forgotten" (Idem 1960: 4).

In the process of arriving at an established policy for overseas tourism, the Overseas Minister, 
Joaquim da Silva Cunha (1920), warned of the necessity "to complete a documented inventory of tourist facilities in all provinces with a view to establishing a general policy for overseas tourism. Included as a first priority should be the preparation of a hotel infrastructure and a plan for its employment." 17 He called for the coordination of metropolitan and provincial services, and the elaboration of tourist propaganda to optimise efforts on both fronts.

In this context colonial architectural projects were developed and railway networks constructed, particularly in the African colonies, in order to welcome the metropolitan traveller and possibly the future colonist who might wish to settle. The building structures resulting from this project reflected a type of Luso-African architecture (Milheiro 2012), the casa portuguesa ultramarina (overseas Portuguese home). With the help of local government the necessary measures were taken to speed up the possibility of overseas travel to the colonies. The promotion of colonial settlement and indigenous "assimilation" resulted in a proliferation of towns and villages named Salazar or Carmona $^{18}$. The coordination for this initiative was the responsibility of the Gabinete de urbanização Colonial do Ultramar [The Overseas Colonial Urbanization Office], established in $1944^{19}$ to construct a "portugalidade tropical" [tropical Portuguese-ness] that demonstrated a "Portuguese way of being in the world" 20 .

The Agência Geral do Ultramar also compiled a line of colonial tourism propaganda literature on numerous occasions in the form of brochures publicising colonial travel and highlighting the attraction of the colonies for the tourist (fig. 2).

The organisation of travel to the colonies began with the Empresa Nacional de Navegação [ENN - National Navigation Enterprise], set up in 1881, whose purpose was to link the capital of the Empire with its African possessions. In 1918 this became known as the Companhia Nacional de Navegação [CNN - National Navigation Company], which until 1922 had a monopoly on maritime travel to Africa. In that year it met competition from the Companhia Colonial de Navegação [CCN - Colonial Navigation Company] that had been founded in Lobito, Angola21. Later on, in the 1950s, the sea route was replaced by
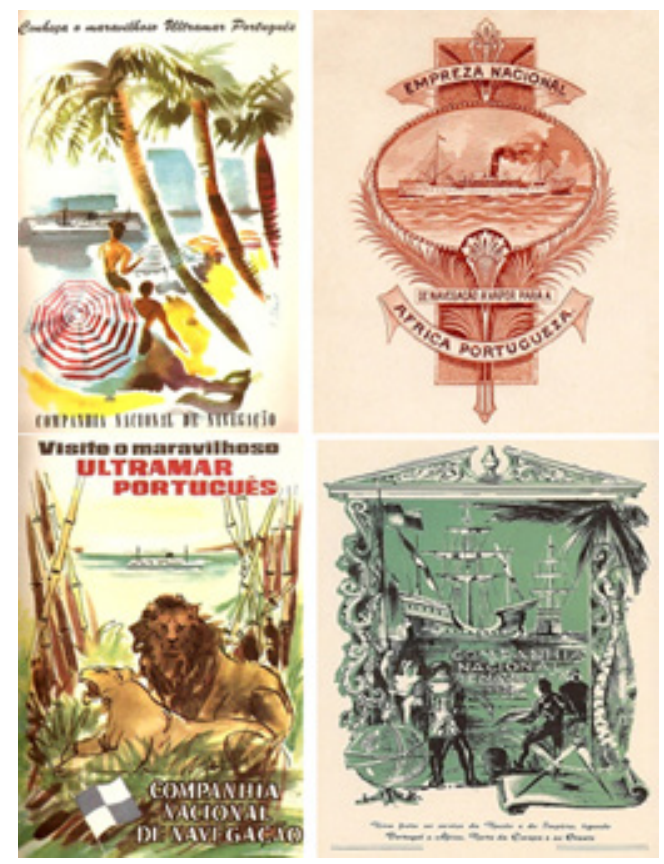

Fig. 2. Colonial tourism posters between 1940 and1970

the airways resulting in the gradual growth of airports in Portuguese Africa.

The possibility of journeying overseas from the capital of the Empire was in large part also due to the Agência Geral das Colónias which in 1924 began distributing colonial propaganda providing information on the territories. This contributed profoundly to the growing taste for colonial travel. Whether travelling for leisure, on business or emigrating, Portuguese citizens tended to keep written records of their journey which helped to document the structure and development of this colonial traffic and contributed to the growth of colonial tourism²2.

\section{Art and Tourism}

Seeking to draw the colonies closer to home, Oliveira Salazar's Estado Novo used art as a vehicle for tourist propaganda - particularly literature and cinema - in a dialogue which would help to promote Portugal as a legitimate, grandiose colonial power. To this end the Concurso de Literatura Colonial [Colonial Literature Competition] was held in 1926 . The event was won by Joaquim Pereira Mota Júnior com Feitiço do Impé- 
rio (The Spell of Empire), a novel which would serve as inspiration for António Lopes Ribeiro (1908-1995) who in 1940 made a film of the same name. In effect, cinema helped to promote tourism in the Portuguese colonies, above all in Angola and Mozambique. In the film adaptation of Feitiço do Império ${ }^{23}$ Lopes Ribeiro emphasised the emergence of a colonial conscience in the protagonist that went far beyond that of the character described in the award-winning novel. But the film's importance lay in its being the first Portuguese fictional film made in Portuguese Africa and including images gathered from the I Missão

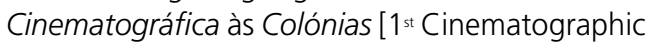
Mission to the Colonies] for which the film maker Lopes Ribeiro was artistic director. The Mission's objective was to demonstrate the positive results of overseas colonisation, a proposal reiterated at the end of the film where the director merged documentary and fictional footage in a final scene where the characters attend the standing ovation given to President Carmona on his arrival in Luanda in 1938, thus showing that the citizens of the metropole should follow his lead and visit the colonies. Most of the documentary footage focuses on the day-to-day existence of the local African population, their customs and traditions. Thus various scenes of dancing, simulated warfare, native markets and so on convey an image of a primitive, exotic Africa, light years away from the daily life of the metropole. One might add that the film creates an imaginary world capable not only of forging a colonial and imperial identity, but also a national Portuguese identity marked by the awareness of belonging to a pluricontinental territory. During the 1960s and 1970s the films portrayed paradisiacal beaches, modern infrastructure and safari photographs with no reference to war ${ }^{24}$.

Painting was also convened in the promotion of colonial tourism. Take Faust Sampaio (18931956), considered an important "painter of overseas Portugal", who toured the African colonies and also Macau, Timor and Portuguese India. Exhibitions of his work in the academic institutions and galleries of Lisbon in the 1930s, 1940s and 1950 s as well as the colonial section of the Grande Exposição do Mundo Português [Great Exhibition of the Portuguese World] in 1940 made him a unique figure among Portuguese painters.

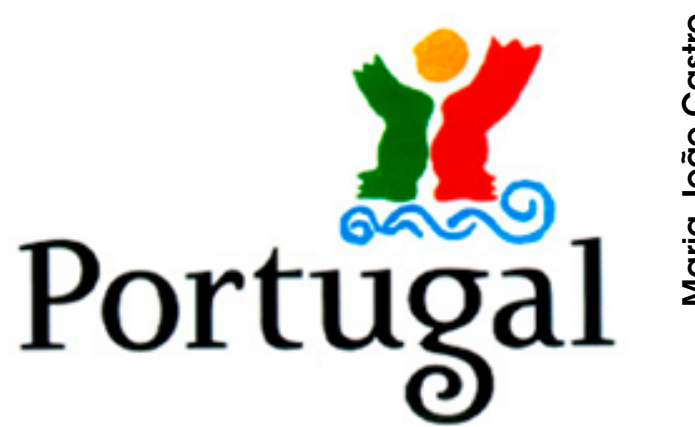

Fig. 3. Portugal Tourism logo. Courtesy José Guimarães, 1992

It was really his paintings which informed the Lisbon public of the landscapes and customs of their territories and helped to encapsulate for most Portuguese people the distant idealism of such destinations.

But there were others who embarked on this overseas pictorial odyssey too but with more modest results. Jorge Barradas (1894-1971) produced the first series of paintings depicting São Tomé, which were exhibited in 1931 at the Lisbon Sociedade Nacional de Belas Artes [National Society of Fine Arts]. Albano Neves e Sousa (1921-1995) had a long career in Angola with regular exhibitions in Lisbon and in various other territories of the Portuguese empire which he regularly visited and painted. He was honoured by the Portuguese Government, receiving the Ordem do Infante D. Henrique [Order of Prince Henry the Navigator] in 1963. In recent times there has been José de Guimarães (1939), an artist whose work since the 1960s in Africa and Asia has illustrated a pluricontinental, multiracial Portugal "from the Minho to Timor" which is so well encapsulated in the symbol for Turismo de Portugal [Portugal Tourism], which he designed some decades ago and is still in use today, particularly the ocean wave, the highway of the Portuguese Discoveries ever since the 15 th century ${ }^{25}$ (fig. 3).

Tourism as the final stage of colonialism or tourism as a new form of imperialism

With the independence of the territories of the European empires, each nation went about elaborating a tourist development plan which took into account the international market and contemplated catering to tourists from the former 
metropole even if it were only for their common language. But this was not the principal factor in the development of post-colonial tourism. The offer of tourist travel to the former provinces grew due to the appeal of revisiting a unique bygone age, with the attraction of specific products such as colonial architecture ${ }^{26}$, the vestiges of a military past such as forts, or simply the legacy of a Portuguese way-of-life in the tropics. Also to consider was the appeal of the exotic and local features: warm water beaches, lush vegetation, resorts equalling western standards of comfort and sporting activities only possible in a tropical climate. These were just some of the attractions promoted for an effective and affective trip.

If in colonial times the journey to the Portuguese territories served as a means to witness, dominate and maintain a world overseas, in the post-colonial era it has served above all to recover a certain "return to the past", distant from western liberal society that has put aside past glories (from the colonist's viewpoint) which can only be recovered through memory. Thus it is not surprising that tourism to the former colonies still caters in particular to the ex-colonist, privileging a common past and a shared language. In fact, the importance of the former colonies as a tourist destination in relation to the destinations chosen by the Portuguese for the purposes of tourism is extremely noticeable in some travel operators, such as Pinto Lopes Viagens ${ }^{27}$.

Acculturation and hybridism make it clear that tourism remains a transversal activity of balances based on a favourable political context. On the other hand, not being an ideologically neutral topic (if it is possible to find such), tourism can be reduced to a single ideological use or particular context. Many theories have tried to explain it in terms of its association with colonialism (Cohen 1972; Nash 1977; Bruner 1989; Crick 1992) in its neo-colonial and post-colonial figurations. In line with these theories centre-periphery power relations create situations of neo-colonial dependency which perpetuate resentment and antagonism in a linear fashion.

Although somewhat paradoxical, many tourists seek destinations whose history is close to their own but which at the same time induce a sense of being "away from home", a mixture of the novel and the familiar. Nonetheless, many theories contend that the tourist's journey in a global world is no more than a new form of imperialism, or rather the final phase of colonialism. For these theorists tourism thrives on inequality, on differences of power and wealth, and as such constitutes a new imperialism, involving a supremacy moulded not by the distant colony but by economic imperatives embedded in the liberal capitalist society of the 21 st century. This is of course a highly reductionist view of the tourist phenomenon and a later issue in the context of this article. Consequently, the means of local subsistence are transformed into subservience where relations between guest and host can be expressed by the economic ascendancy of the former over the latter.

The whole scenario is contradictory: does tourism destroy the culture it seeks, or does it sustain the culture by reinventing it?

\section{Not-so-final considerations}

The high degree of mobility in the contemporary world raises a paradox: while people may travel anywhere and at all times, this ease and accessibility of movement has, on the other hand, probably made the world less "exotic" and diverse. This does not invalidate the fact that many of the old European colonies have been "recolonised", this time by the capitalist free market on a planetary scale which homogenises destinations and products in a way that makes them attractive to mass consumption by world tourism. We are speaking then of tourism as a form of colonialism based on the idea that "the old formulas of imperial conquest have given way to a new invasion ... tourists" (Holland 2003: 164).

Without doubt Tourism and Colonialism maintain close ties in the post-colonial era, regardless of how one might wish to correlate them. Reflection on the binomial of tourism/colonialism is far from being exhausted and there is a lack of more in-depth studies consubstantiated by a transnational history that integrates the Portuguese universe with that of the European colonial empires, taking into account their particularities. That there is a common history to the colonial empires of the Old Continent and because this history has consequences and a legacy in the con- 
temporary world is indicative of a worldview that has repercussions all over the globe ${ }^{28}$.

One searches ever more diligently for the colonial tourist experience where a common past is a guarantee of a close identity. In this regard the countries of the old Portuguese empire occupy a privileged position as consecrated destinations with a shared memory. Between neo-colonialism and post-colonialism, travel-tourism and empire come together as an enticement to overseas travel, constituting a privileged indicator of an interdependent existence which has survived beyond the end of European colonialism. One only has to witness the commitment in cultural policy that results, or will result, in agreements and protocols being signed between the old colonial na- tions and the governments of newly independent nations who are today bilateral partners. In the case of Portugal, the proliferation of agreements with countries like Angola, São Tomé e Príncipe, Mozambique, Cape Verde or Timor reflects the building of solid relations, beyond memories of the colonial war, albeit not exempt from criticism and difficulties.

Certainly in the contemporary post-colonial era the invitation to travel has enabled the construction of a worldview of tourism similar to the geography of the planet, sustaining places of colonial reference at home and overseas which constitute mythical windows on a reality which will undoubtedly continue to resonate. 


\section{NOTES}

${ }^{1}$ The journey around the world was made by using the technique of the 'moving panorama' in which the circular exhibition was replaced by a moving canvas. A person left from Marseille, visited a variety of countries and afterwards returned to the point of departure. This panorama in which movement was added to the static picture was amazingly successful in realising the ideal of a journey around the world without leaving the metropole.

${ }^{2} \mathrm{See}$, by way of example, the publications of Eduardo Coelho, Passeios no estrangeiro: visita à exposição de Paris, passeio a Londres, passeio na Bélgica e no Rheno, Lisboa, Typografia Universal, 1879; Ramalho Ortigão, Notas de Viagem: Paris e a Exposição Universal (1878-1879), Lisboa, Clássica, 1945; A. Cavaleiro Sousa, Uma visita à Exposição Universal de Paris em 1889, Lisboa, Lucas \& Filho, 1893; António Melo, Um barquense na Exposição Universal de Paris de 1900: apontamentos de viagem, Ponte da Barca, AL-Publicações, 2013.

${ }^{3}$ Thomas Cook (1808-1892) was one of the first travel agents in the world, who, by hiring a train, created the first group touristic journey. After that, he began to contract the services of different agents with the aim of selling a tourist "package" (which included travel, accommodation, visits and meals), thus contributing to the emergence of mass tourism.

${ }^{4}$ Rebaptised in 1944 as the Secretariado Nacional de Informação, Cultura Popular e Turismo [SNI -National Secretariat for Information, Popular Culture and Tourism].

${ }^{5}$ Decreto n. ${ }^{\circ} 30251$, de 30 Dezembro 1939 and Decreto n. ${ }^{\circ} 30289$, de 3 de Fevereiro de 1940.

${ }^{6}$ In 1907 Prince D. Luís Filipe visited the African colonies and in 1908 a trip by D. Carlos I to Brazil had been programmed but the regicide nullified this.

${ }^{7}$ Decreto-Lei n. ${ }^{\circ} 42$ 194, de 27 de Março de 1959.

${ }^{8}$ These Fairs did not have any directive to make tourist propaganda but rather concentrated on promoting trade and developing the economy.
${ }^{9}$ See "Informações das Casas da Metrópole de Luanda e Lourenço Marques", Separata N. ${ }^{\circ} 293$, Boletim Geral das Colónias, Lisboa, AGU, 1949, p. 7.

${ }^{10}$ Decreto-Lei n. ${ }^{\circ} 41$ 407, de 28 de Novembro de 1959.

${ }^{11}$ Created by Decreto-Lei $n^{\circ} 23445$, de 5 de Janeiro de 1934.

${ }^{12}$ Portaria n. ${ }^{\circ} 18111$, de 7 de Dezembro de 1960.

${ }^{13}$ See Norberto Cardigos, À margem do I Cruzeiro de Férias às Colónias, Aveiro, Gráfica Aveirense, 1936.

${ }^{14}$ See Roteiro do $1^{\circ}$ Cruzeiro de Férias dos Estudantes das Colónias à Metrópole no ano de 1937: Iniciativa do Ministério das Colónias, Lisboa, Sociedade Industrial de Tipografia, 1937.

${ }^{15}$ The newspapers of 2.9.1939 published an official note from the Government in which the Government declared Portugal's neutrality in the conflict.

${ }^{16}$ It is worth opening a parenthesis here to mention that, within the context of presidential journeys, it was not only presidents who were called on to travel around the Portuguese overseas territories but that these propaganda events also included the ministers for the colonies. Bacelar Bebiano (1894-1967), Armindo Monteiro (1896-1955), Vieira Machado, Marcello Caetano (19061980), Sarmento Rodrigues (18991979), Raul Ventura (1919-1999) and Adriano Moreira (1922) all scheduled their trips to the overseas colonies to intercalate with presidential journeys, thus assisting the colonial propaganda policy and contributing to the views of the people being heard. This ministerial dynamic was underlined by Marcello Caetano himself in his Discursos edited by the Agência Geral das Colónias in 1946, in which he stressed that the visit of the Minister for the Colonies to the overseas territories would cease to be a sporadic and extraordinary event but would become a normal act of the administration.

17 See Política do Turismo no Ultramar, J. M. da Silva Cunha, separata do Boletim Geral do Ultramar, Lisboa, Agência Geral do Ultramar, 1966, p. 14.

${ }^{18}$ By way of example, see how in Angola Dalatando became Vila Salazar (1936) and Uíge became Vila Marechal Carmona (1955).
${ }^{19}$ Decreto-Lei n. ${ }^{\circ} 34173$, de 6 de Dezembro de 1944.

${ }^{20}$ An expression coined by Adriano Moreira (1922), professor and Overseas Minister of the Estado Novo (1961-63) which was widely reproduced by the propaganda of Oliveira Salazar's regime.

21 See http://restosdecoleccao. blogspot.pt/2011/12/companhia-nacional-de-navegacao-cnn.html (accessed on 29.8.2017).

${ }^{22}$ For a non-exhaustive bibliography see: Francisco José de Lacerda e Almeida, Documentos para a história das colonias portuguezas: diario da viagem e Moçambique para os rios de Senna, Lisboa, Imp. Nacional, 1889; Armando Augusto Gonçalves de Moraes e Castro e António Pereira Cardoso, Uma viagem através das colónias portuguesas, Porto, Companhia Portuguesa Editora, 1926; Julião Quintinha, África Misteriosa. Viagem às Colónias, Lisboa, Nunes de Carvalho, 1931; Arnon de Mello, África: viagem ao Império Portuguez e à União Sul-Africana, Rio de Janeiro, José Olympio, 1941; F. Pimenta de Carvalho, Impressões de uma viagem ao Ultramar, Arganil, [s.n.], 1965.

${ }^{23}$ The film tells of the spell cast by the Portuguese overseas territories over Luís Morais (Luís de Campos), a young Luso-descendant whose family lives in Boston. Luis is getting ready to marry an American girl, Fay Gordon (Madalena Sotto), and to become a naturalized citizen of the United States but he is persuaded by his father Francisco Morais (Alves da Cunha), a wealthy Portuguese emigrant, to visit Portugal and her African colonies before finalising these decisions. Primarily attracted by the chance to hunt in Africa, Luís is not particularly impressed by Lisbon where he disembarks first. However, the protagonist cannot resist the fascination of Overseas Portugal, where his "conversion" to Portuguese values takes place and which he ends up embracing at the end of the film. It is the colonial journey that awakens the protagonist to an awareness of "portugalidade" [Portuguese-ness], assisting at his transformation in the paradigm of the "new man" who emerges through the synthesis of the Portuguese world "from Minho to Timor". 
${ }^{24}$ Viagem no Deserto, by António de Sousa Portugal, 1967 / 19 min; Beira: Porta Turística de Moçambique, by Miguel Spiguel Portugal, 1973 / 11 min; and Horizonte Angolano, by Elso Roque and João Mendes Portugal, 1973 / 15 $\mathrm{min}$, are but a few examples of the films made.

${ }^{25}$ José de Guimarães thought that it was important that the symbol represented Portugal as an Atlantic country and, retaining the idea of a mythical figure found in fables, he transformed this into a being capable of walking on the waters of the oceans, thus linking it to the history of navigation and the Discoveries. Inspired by the national flag, he painted two open hands in red and green, spreading them out into a body whose head, in the shape of the sun, represented the warmth of both the country and its people. Finally the font takes up the spirit of the original symbol through a spiral shared by the letter " $g$ " and the wave it rests on. To follow the development of the idea, see Viagem do artista. Journey by an artist, Lisboa, ICEP, 1993.
${ }^{26}$ On this subject, see McLaren, Brian (2006) Architecture and Tourism in Italian Colonial Libya: An Ambivalent Modernism, USA, University of Washington Press.

27 See https://www.pintolopesviagens.com/viagens-com-autores/raquelochoa/ (accessed in 15.4..2018).

28 See https://www.theguardian. com/commentisfree/2014/apr/08/ people-beautiful-colonial-tourism-travel (accessed in 29.8.2017). 


\section{REFERENCIAS}

Andrade, Ferreira. 1960, Anuário do Turismo do Ultramar de 1959. Lisboa: Ferreira de Andrade.

Baranowski, Shelley. 2015. "Tourism and Empire." Journal of Tourism History, United Kingdom, Tailor \& Francis Online.

Brito, Sérgio Palma. 2003. Notas sobre a evolução do viajar e a formação do turismo, Lisboa: Medialivros.

Cadavez, Cândida. 2017. A bem da nação. As representações turísticas no Estado Novo entre 1933 e 1940, Lisboa: Edições 70.

Cardigos, Norberto. 1936. À margem do I Cruzeiro de Férias às Colónias, Aveiro: Gráfica Aveirense.

Crick, Malcolm. 1992. "Representaciones del turismo internacional en las ciencias sociales: sol, sexo, paisajes, ahorros e servilismos." In Los mitos del turismo, 320-403. Madrid: Endymion.

Cunha, J. M. da Silva. 1966. "Política do Turismo no Ultramar." Boletim Geral do Ultramar, Lisboa: Agência Geral do Ultramar.

Davidson, Jim, and Spearritt, Peter. 2000. Holiday Business: Tourism in Australia since 1870, Carlton: The Miegunya Press at Melbourne University Press.

Direcção Geral de Turismo. 1991. Portugal. Livro Branco do Turismo, Lisboa: Ministério do Comércio e Turismo.

Garcia, José. 2011. Ideologia e propaganda no Estado Novo: da Agência Geral das Colónias à Agência Geral do Ultramar 1924-1964, Coimbra: Faculdade de Letras, Universidade de Coimbra.
Hobsbawm, Eric. 1990. A Era do Império. 18751914, Lisboa: Presença.

Holland, Patrick. 2003. Tourists with Typewriters. Critical Reflections on Contemporary Travel Writing, United States of America: The University of Michigan Press.

Jamal, Tazim. 2012. The SAGE Handbook of Tourism Studies, California: Sage.

Milheiro, Ana Vaz. 2012. Nos trópicos sem Le Corbusier. Arquitectura luso-africana no Estado Novo, Lisboa: Relógio d'Água.

Nash, Dennison. 1977. "Tourism as a Form of Imperialism." In The Anthropology of Tourism, 33-47. Philadelphia: University of Pennsylvania Press.

Portugal Colonial, revista de propaganda e expansão colonial, Accessed August 18, 2017. http://hemerotecadigital.cmlisboa.pt/Periodi$\mathrm{cos} /$ PortugalColonial/PortugalColonial.htm

"Roteiro do $1^{\circ}$ Cruzeiro de Férias às Colónias nos meses de Agosto e de Setembro de 1935." O Mundo Português, Lisboa: Gráfica da Sociedade Industrial de Tipografia.

Roteiro do $1^{\circ}$ Cruzeiro de Férias dos Estudantes das Colónias à Metrópole no ano de 1937 Iniciativa do Ministério das Colónias, Porto: S.I.

Said, Edward. 2011. Cultura e Imperialismo, São Paulo: Companhia de Bolso.

Thuram, Lilian. 2011. Exhibitions, L'invention du sauvage, Paris: Coédition musée du quai Branly / Actes Sud.

Urbain, Jean-Didier. 2002. L'ldiot du Voyage. Histoires de Touristes. Paris: Éditions Payot. 